\title{
The Political Contribution of Albanian Writers in Defining Albanian Identity: the Debate between Ismail Kadare and Rexhep Qosja
}

\author{
Përparim Xhaferi \\ The University of Sydney, Sydney, Australia
}

\section{Abstract}

This paper will explore some elements of the contested notion of Albanian identity through a short analysis of the thesis put forward by the Albanian prominent writer, Ismail Kadare. Kadare claims that Albania belongs to the European family, and the Ottoman 'barbarians' unjustly 'removed' Albania from Europe for five centuries. His main opposing voice, Kosovar academic, Rexhep Qosja, rejects Kadare's Albanian identity interpretation. In contrast to Kadare, Qosja argues that the Albanian identity has more similarities with Oriental-Eastern culture, and therefore, does not reflect Europe. Religious controversy is present on both sides. The paper will explore how expansive contribution of both Albanian writers, while appreciated, has also been instrumental in defining the Albanian identity. The Kadare-Qosja argument is the overarching question with regards to Albanian identity, which is still polarising Albanians. After a short analysis of the Kadare-Qosja debate, this paper will emphasise some opinions of the Albanian analysts, media, writers and politicians. The paper will then conclude with some remarks, as Kadare, Qosja, and others need to constructively debate the Albanian identity question and avoid drawing on personal differences between the two; which for obvious reasons do exist.

Keywords: Albanian identity, European family, culture, religion, Kadare-Qosja debate

\section{Introduction}

The political contribution of Albanian writers in defining Albanian identity: The debate between Ismail Kadare and Rexhep Qosja. One of the best Albanian contemporary writers, Ismail Kadare, along with his extensive writings, has emphasised Albanian identity as his main theme. Kadare is convinced that Albania belongs to Europe, and therefore, there is compatibility between Albanian and European identity. The Albanian-European identity includes religion, which according to Kadare follows that of 'Christian Europe'. On the other hand, Professor Rexhep Qosja argues that the Albanian Muslim majority cannot be ignored, and along with that, Albanian identity has more similarities with Eastern civilization.

Since 2006, both Kadare and Qosja have been actively engaged in debates regarding Albanian identity - a paramount that cannot be treated as a secondary question. The dynamics of exchange essays between Kadare and Qosja since 2006 deserve to be captured in a context of exploring the nucleus of their debate: The Albanian identity definition. Although both authors are the best Albanian contemporary writers, only a few of their essays are translated into English, which shows lack of research in this area. The latest essays of Kadare and Qosja analysed in this paper are not translated into English yet; therefore the author is responsible for any error of translation or possible mistakes.

The decision of some Albanian politicians to side with 'Albanian-European-identity' and support Kadare's Albanian identity thesis can be instrumental, while guiding Albania toward the Euro-Atlantic orientation. The Albanian-speaking analysts, media, writers and politicians are also involved in this debate between the two Albanian 'giant' writers. Their opinions vary in siding with one, the other; and whether to agree with them or against both of them. While disagreements show the complexities of defining Albanian identity, the focus of this debate needs to shift on discussions about Albania's past, present and future, rather than drawing on writers' personal differences.

\section{Kadare: a Modern Homer and the Albanian Aeschylus}

So much of what we know and understand about Albanian identity is due to the master narratives of Ismail Kadare. This is particularly true at the level of emotional, physical and psychological trauma of the Albanian nation, which often gets lost in larger narratives of the Ottoman period. Kadare successfully transcribed Albanian folklore to a modern written style. As John Carey describes, Kadare, who creates the entire map of the Albanian culture, its history, passion, folklore, politics and 
disasters, "is a universal writer in a tradition of storytelling that goes back to Homer" (Kadare, 2011, p. back cover). Peter Morgan found that Kadare, who is "conscious of his obligations" to connect the "break between Illyro-Albanian culture" and modern Albania, "is' Aeschylus" (Morgan, 2009, p. 292). For Kadare, Aeschylus is the character "who forged the transitional path from the oral legacy of the Homeric Greek to the written forms of modern literature" (Morgan, 2009, p. 285). Therefore, Kadare, the 'Albanian-Aeschylus', is convinced of his duty to his motherland to convey its ancient folklore and epic songs (as Aeschylus did with Greek literature), to contribute to defining Albanian identity.

Kadare has been persistent in uncovering the ancestral roots of Albanian identity. During the 1970s and 1980s, when he produced his seminal essays Aeschylus, the great loser and The Palace of Dreams, Kadare asked questions about his origins and "the authentic core to the Albanian existence", as he did in The Shadow going back in the period of "Christian Albania in the Middle Ages", before the Ottoman conquest (Morgan, 2009, p. 298). For Kadare, the Ottoman occupation and communist regime in Albania negatively affected Albanian identity, disrupting the integrity of Albania's European culture.

\section{Kadare's Ancient Albanian Identity}

Based on archeological facts and historical studies, Kadare envisages the Greco-Illyrian civilization as the oldest in the Balkan Peninsula. In his essay, Aeschylus, Kadare advances his "imaginative evocation" of similarities in "the original Greek and Illyrian civilization of Homeric antiquity" (Morgan, 2009, p. 299). Kadare believes that Illyrian-Albanian culture resided in the Balkans before the Slav migration, as "Albanian Christianity was older than that of Serbia" (Kadare, 2006, p. 44).

According to Kadare, upon the arrival of the Ottomans, at the end of the fourteenth century, "a new faith was introduced to our [Albanian] ancestors, Muslim faith and its mosques" (Kadare, 2006, p. 25). For Kadare, as a result of "the clash of two civilisations", Oriental-Ottoman Empire and Occidental-Europe, the Balkan Peninsula (considered "the cradle of [Europe's] civilization"), was removed from the body of the old "mother" (Kadare, 2006, p. 59). However, if little Albania was physically removed from the 'body' of the 'mother' Europe, what happened at a cultural and spiritual level?

Kadare is convinced that Albanian identity was not affected by the Ottoman conquerors, as "nations cannot be changed by occupations or conversions" (Kadare, 2006, p. 51). While in the earlier Aeschylus essay, Kadare discussed "Albania's European credentials", in his later 2006 essay, Identiteti evropian i shqiptarëve [The European identity of the Albanians], he aimed to create the "intellectual and spiritual environment" that can be seen as his contribution to "a new and more profound reattachment of Albania to its European heritage" (Morgan, 2009, p. 299). In fact, throughout his writings, Kadare maintains this thesis, that Albania is part of Europe. In The European identity essay, he supports his claim with reference to geography, "which is hard to argue with" (Kadare, 2006, pp. 20-21). Kadare's line of separation between Occident and Orient "verifies Albanian Europeanism" (Kadare, 2006, p. 21); race, as he thinks the "Albanian population, as the entire European continent, is white", and its ancestors are "at best Illyrians, or at worst Thrace-Illyrians"(Kadare, 2006, p. 21); the Albanian national hero Skenderbeg, whose name was mythicized not only by Albanians but also by Europeans (Kadare, 2006, p. 22), at a point that his dead body disappearance was compared, as an analogy, to be "the same as Jesus" (Kadare, 2011, p. 54); the similarities of the Albanian kanun and këngët e kreshnikëve [epic songs], with European epics, which start from Diogenes, "one of the creators of European culture", until 'the "Saxo Grammaticus", which in 1200, dedicated around forty pages on the history of the "blood feud of the prince Hamlet" (Kadare, 2006, pp. 22-23); Kadare has a high regard for the Albanian language, which according to him, at early stages was written in Latin languages and had been a driving force to unite Albanians as its power has been "above the state" (Kadare, 2011, p. 69). In short, Albania never changed her national identity and thus, is still part of Europe.

In one of his last books, Bisedë për brilanted në pasditen e dhjetorit [Conversation for brilliants on a December afternoon], Europe is described as "a strange star, very dense, a sort of colossal diamond...a brilliant" (Kadare, 2013a, pp. 111-112), which is more important than anything else; "hanging perhaps in the sky" but being "cold and useless such as death" (Kadare, 2013a, p. 112). While Kadare deliberately baptized Europe as a "diamond", on the other hand, Europe has also been "cold" and helpless to protect the Balkans - its 'cradle of civilization'. However, for Kadare, this enormous diamond is illuminating Albania's way to join Europe. The 'mother' Europe has been "absent" and "late for many years" (Kadare, 2013a, p. 111), however, for Kadare, the "lost and re-found of the mother continent, does not make you [Albanians] less European than others. In contrary, it makes you more" (Kadare, 2006, p. 59). Thus, the Albanian nation with a 'European-Latin' language and cultural similarities with those of Europe needs to rejoin the European Union. Kadare is obsessive in his quest to rejoin Albania with Europe. He is also very anxious to distance Albania from its Ottoman past. 


\section{Kadare's Rhetorical Techniques in Creating 'Others'}

At times, when the Albanian nation building process is on its way, Kadare "remains fuelled by the same fears" that this process can also "capitulate again to internal as well as external forces of destabilization" (Morgan, 2015, p. 14). In one of his last essays, Secret relation, Kadare's creative characters communicate through an emotive language that is directed to different audiences. His invented character 'Tuz efendiu' (a high Ottoman figure that perhaps was made to represent the Sultan Mehmeti II) is coming to visit Albanian pashaliks after the death of Skenderbeu. Tuz considers the European continent as "threatening, without soul" (Kadare, 2013b, p. 125). While Albanian people are speculating about the purpose of his visit, some of them thinking that Albania is important in the Balkans, others are claiming that Tuz efendiu is "preparing the big attack against Europe". Tuz himself cannot stop thinking about Gjergj Kastrioti's empty tomb that became a myth (Kadare, 2013b, p. 118). Skenderbeu's disappearance deeply troubles him. One of the local Albanians speaking to Tuz efendi states:

Our Osman state will soon swallow Europe. I once saw a python swallowing a gazelle. It was terrible, but beautiful. This is what is going to happen; the swallowing [of Europe] will start just here; the Balkans (Kadare, 2013b, p. 134)

This imagery is used in order to reach out to different audiences. While it reminds the Albanian resistance to halt the destructive effects of the Islamic-Turks that arguably might have been spread to Europe, it also compares the Turks with a snake that swallows a beautiful gazelle. In short, one can argue that Kadare's emotive language is addressed externally to the West, Orient and Albania's neighbors, but also to Albanians themselves - "the four others of the Albanian nation" (Jing, 2013 , p. 48) that Jing Ke has found in analyzing Kadare's work. However, Ke's analysis in finding Kadare's shift to consider the west from "the hostile other" to become "the dear Mother of the Albanian nation" (Jing, 2013, p. 226) is very simplistic. Kadare at the age of 22, in 1958, "was sent to the Soviet Union for his professional education" to write in a socialist-Soviet style (Morgan, 2009, p. 38), however, at Gorki Institute he was also exposed to western literature, which at the time was penetrating Russian regime. Kadare "begun to draw his own conclusions" (Morgan, 2009, p. 38), and thus, his criticisms toward the west need to be read carefully, in context of time and circumstances in which were written. Nevertheless, Kadare's -'others' of Albanians - are unchanged: the Oriental-Turk, Serbian nationalistic ideology and those Albanians that since the fourteenth century have been working against Albania's interests, remain enemies.

\section{The Post-Ottoman Era: Religion's Role in Nation Building}

Kadare thinks that the rilindja period was very decisive in paving the foundation of today's Albanian nation and its identity. During the rilindja period from the scrimmage of three Albanian faiths Catholic, Muslim and Orthodox, "the miracle happened: three faiths" lent respect and loyalty to "Albanianism" (Kadare, 2011, p. 68).

The harsh medieval formula, "Where is sword, lays religion", was replaced with the soft approach: "The Albanian faith is Albanianism" (Kadare, 2006, p. 33)

For Kadare, Albanianism has always been above religion. One example used by Kadare is the self-proclaimed MuslimAlbanian-King, Ahmet Zogu who attempted to create a new "European Muslim" (Kadare, 2006, p. 36) hence; he was in a hurry to approve the legislation, which regulated "the relation of [Albania's] three religions and the state", as he understood Albania's survival while separated from Europe was impossible (Kadare, 2006, p. 35). The new "European Muslim" now had to comply with Zogu's policies such as the prohibition from using the white Turkish fez for men, the hijab for women, and the direction to pray while standing, rather than sitting on their knees - as this would clash with the old Albanian kanun, which protected Albania's male pride. As he mentioned, one cannot force an Albanian man to sit on his knees (Kadare, 2006, p. 35).

\section{Kadare-Qosja Debate}

Kadare's Albanian identity thesis is strongly opposed by Professor Rexhep Qosja - a long-standing intellectual figure in Kosovo who pays a role in Albanian literature, a historian and a critic who is also very active in politics and social science. The debate between the two was sparked in 2006, with the publication of Kadare's essay, Identiteti Europian i Shqiptarëve [The European Identity of the Albanians], and became incandescent when Qosja responded in the same year with his essays Idetë raciste të Ismail Kadaresë [The racist ideas of Ismail Kadare], Ideologjia e Shpërbërjes [Disbanding Ideology] and Realiteti Shpërfillur [Neglected Reality] (Toena, 2006). A summary of Qosja's disagreement with Kadare is published (Qosja, 19 April, 2006) on his own website created by AlbaNur, and will be analysed throughout this paper. 
Qosja thinks that Kadare's theses that were put forward in his essay, The European Identity, reveal "the cultural disagreement between Europe and Muslim-East, while...it shows superiority of the European identity towards...Muslim identity!" (Qosja, 19 April, 2006). Qosja argues that it is a racist assumption to ignore the Albanian Muslim community that is a majority in Albania and Kosovo, and to therefore equalise Albanian identity with that of 'Christian Europe'.

While for Kadare, this identity has remained unchanged and clearly belongs to the European-Christian civilization, Qosja thinks that Albanian identity is a mixture of two civilizations: "Christian and Islamic". However, for Qosja, "Islamic civilization" in Albania is more widespread than the "Christian civilization" (Qosja, 19 April, 2006). Qosja centres his claim on Albania's culinary culture; folk dress; songs and dances; death and birth ceremonies and their rules; gender culture; morals and laws; pop art that have Turkish and Arab similarities; religious, illuminist, pedagogic and moral literature written in Arabic; architecture of the Albanian cities; bridges, mosques, tekkes and tyrbes built during the Ottoman occupation, which, according to him, are all part of the "Islamic civilization" (Qosja, 19 April, 2006).

The Albanian religious dichotomy creates strong divisions between the two Albanian writers with regard to the Ottomans and their Islamic religion. While for Kadare the Ottomans represented Islam, backwardness, intolerance and barbarism, Qosja disagrees, reminding us that the Ottoman Empire was also "religiously tolerant" (Gawrych, Novembre 1983; Qosja, 19 April, 2006). In addition, Qosja thinks that, at the time, the Ottomans were no more "barbarian" than other European Empires, as was shown during the period of Christian crusades. Hence, while for Qosja, Islam is part of the Albanian identity, Kadare posits Islam as 'other' for the Albanian identity. Kadare thinks that during their protests in 1981 and 19891990, Kosovar students fought for freedom, not for Islam (Kadare, 2006, pp. 43-44), whereas Qosja believes the students fought not for Christianity either, but for a simple request: to see Kosovo as a republic, which must be united to "what was then called, the mother state - Albania" (Qosja, 19 April, 2006). Kadare's position with regards to Islam not only seems to be an emotional statement, but also instrumental during the Albanian national building process of the post-Cold War period.

Qosja went as far as revealing his position against "mythicising Mother Teresa" in Albania, who for him, is a religious figure and, therefore, the "name, portrait and her statue must be present at religious, humanitarian or health institutions, but not at Tirana airport, political, state institutions and city plazas" (Qosja, 19 April, 2006). Qosja thinks that the Albanian politicians (including Kadare who is not a politician) use a religious figure "in a multi-religious country" to achieve their political ends. Hence, it is not hard for one to grasp Kadare's 'sympathy for Christian Europe', as it is the same for Qosja with regard to 'Albania's Muslim heritage'.

The reality is that while Qosja tries to paint a realistic picture of Albania's current religion, Kadare is going back in history to discover the 'unchanged' Albanian-Christian religion. Qosja thinks that Albanians have different religious identities such as "Catholic, Orthodox, Muslim, Protestant, Atheist", however, all unite in what he calls "the Albanian national identity" (Qosja, 2006, p. 28). Kadare instead, ignoring other religious composition of Albania, thinks that the "cards are clear" for Christian-Albania to join Europe. This is not the case for Qosja's Albania with mixed religious identities, or 'more' Muslim identity, which, following Qosja's logic, is not yet ready to join the Christian Europe (Frashëri).

Kadare argues with Qosja that identity is not something fleeting that can alter quickly, whereas for Qosja, national identity can be transformed and changed, absorbing new elements, as it did in Albania's case. Qosja's position with regards to Albanian identity is strongly contradicted by Kadare who, in his essay, The European Identity, thinks that Albanian identity cannot be "half", which in Albanian language means "torollak [fool]" (Kadare, 2006, p. 55), but must be entirely Occidental - the same as European identity. Kadare refers to the Kosovar identity as an example that, according to him, did not change under the Serbian rule.

Qosja on the other hand, considers Kadare's thesis racist (Qosja, 3 May 2006, p. 34); arguing with some of those factors that Kadare brings forward to prove the Albanian-European identity, such as geography, the Albanian 'race', the role of bilingual Albanian-Latin literature and his emphasis with regard to religious dichotomy of Albania. Hence, Qosja considers Kadare as 'Orientalist' and 'Muslimanist' in Edward Saied's style.

Qosja culminates his debate in opposing Kadare, who considers the Albanian population to genetically have 'white color of the skin': the same as Europeans. Thus, he calls Kadare's thesis dangerous, as they want to keep Albanians far from Asians and Africans at times when Europe is a unification of nations, cultures and languages, and is not created based on 
the race or skin color. Europe has shifted from that concept for some time now, and European countries have, in their composition, people with different colours who share the same rights with white Europeans (Frashëri).

While Kadare blames the Ottomans as primarily responsible for wreaking destruction of Albania, both Kadare and Qosja criticise great powers for their lack of interest in protecting Albania and their reluctance to recognise Albania as a nationstate after the independence proclamation on 28 November 1912. Both Kadare and Qosja also criticise Europe for its negligence regarding the Albanian case, all those Albanians who work against the national interest, and they both have high regard for Albanian rilindja writers. Thus, Kadare and Qosja contemplate the same 'others' for the Albanian identity, with one exception: the Ottoman-Turks and their religion.

\section{Two Distinctive Writing Styles - Different Interpretations}

It is important to remember that Qosja and Kadare - one geg and the other tosk - are writing in very different styles, attacking each other in a way that Frashëri calls the Albanian "sanguine temper" (Frashëri) - another characteristic element of the Albanian identity. While Kadare is a great writer and novelist, Qosja tries to academically probe the Albanian identity question, however, despite the fact that they are both Albanian giants in the field of literature, they both possess extensive knowledge, but argue in the wrong field (Frashëri). They also grew up in very different environments, which shaped their ideas. Kosovo was annexed into Yugoslavia and its economy under Tito enjoyed relative progress compared to that of the remote-centralised Albania. Therefore, Kadare and Qosja's paths were divided from the beginning.

For Qosja, as a Kosovar, the Serbian-Orthodox enemy was extremely visible, and existed outside the Albanian community. Along with the Albanian language, the Kosovar-Muslim religion acted as an important bond to oppose the Serbian orthodox religion, which was used by Serbian nationalism against Kosovar-Albanians. For Kadare, instead, 'the Albanian enemies' - the Islamic-Ottomans, Russian and Chinese imperialists, were easy preys, however, this was not the case with the Albanian-atheist-communist regime during the cold war period. In short, for Kadare religion played only a limited role in safeguarding Albanian identity. Although things have changed in the last two decades, Kadare is openly trying to revitalise the importance of Albanian identity and its ancestral Christian religion.

\section{Albanian Politicians siding with Kadare}

Since the end of the Cold War, in Albania, a bi-partisan political support for Kadare's thesis of a European-Albania is noticed (F. Nano, 12 September, 2002). The post-Cold War discourse of the Albanian elite is a chorus echoing the West and its values, and Kadare is considered the spiritual leader. Some Albanian politicians are convinced that it is only by returning Albania to the 'European family' that issues like security and economic needs will be resolved. Supporting Kadare's theses, they consider Albanian culture as part of Western Europe. At the peak of the debate, when Qosja criticised Kadare in his essay, The racist ideas of Ismail Kadare, the former head of the Albanian Parliament, Jozefina Topalli, was quick to state that "Albanians have a European identity" ("Topalli mbështet Kadarenë: Kemi Identitet Evropian [Topalli support Kadare: We have European Identity]," 31 May, 2006). Former Albanian President Bamir Topi did the same, stating: "Albania must return to Europe... to which it belongs both historically and geographically and from its spiritual vocation" (Topi, 7 February, 2008). Topi's predecessor, Alfred Moisiu went even further in one of his speeches, stating that "every Muslim Albanian carries 15 centuries of Christianity in his/her soul" (Moisiu, 10 November, 2005). In his statement, Moisiu ignored three decades of a dysfunctional Albanian state between 1912 and 1944, half a century of communist-atheism, and two and a half decades of a wild transition-anarchy and corruption culture - a new 'religion', which is neither Christian nor Islamic, but seems to be part of the Albanian fabric. Therefore, these statements demonstrate a political decision toward the 'EuroAtlantic Orientation' as the only way that the Albanian state-building process 'must go'.

\section{Differentiating Albanian Scholarly Opinions - Pro or Against Kadare}

Challenges regarding Kadare-Qosja debate are reflected on divisive positions and interpretations of Albanian scholars. The Albanian historian Kristo Frashëri suggests that both Kadare and Qosja are focusing too much on religious identity issues and they are missing the real debate about Albanian identity (Frashëri). For Frashëri, Kadare's thesis needs correction, whereas all Qosja's analyses are wrong, as Albanian identity should be understood out of religious bias; other elements such as Albanian language and culture can better explain it. In fact, while both Qosja and Kadare try to better explicate the Albanian and European identity, they also seem to be confined within religious and their own personal disagreements. 
Frashëri thinks that both Kadare and Qosja are confusing "identity" with "civilization" (Frashëri). For him identity is a "nation's property" and cannot be changed, whereas civilization is very dynamic and continually absorbs new elements (Frashëri). It can be argued that Frashëri's 'unchanged identity' sides with Kadare's theses, and on the other hand, opposes Qosja who equalises the "religious civilisation", which for Frashëri does not exist, with that of 'western and eastern civilisation'. Although for him, Islam and Christianity are guided by their 'static' policies, little changes are made to reflect continuous developments. However, Frashëri notes that "religion has no power over civilization" (Frashëri), but rather follows civilisation developments. Hence, Islam and Christianity cannot be identified with "eastern" and "western" civilisations respectively, as "religion is different from civilisation" (Frashëri).

According to Besnik Pula, Kadare's description of "Islamic 'Turks' as the antinomy of 'Western' Christian Albanians" was transformed "a standard theme in the Orientalist historical narratives of Ottoman expansion in Europe" (Pula, 2006, pp. 7677). In his book, Escaping from the East, Enis Sulstarova offers a detailed analysis of Kadare's shifts who describes the Turks as "barbarians of a lower race set to conquer and destroy all of Christian Europe" (Pula, 2006, pp. 74-77). As the review of Sulstarova's book astutely notes:

What is more interesting, Sulstarova finds the themes of Kadare's works to reflect major policy shifts in Albania, and with it, the subject representing the Orient in Kadare's works shifting as well. ... In one of his novels, the Chinese communist leadership seems set on using Albania as a pawn which the large Asian country was to use in a cunningly secret plan to dominate all of Europe. ... Soviets and the Chinese representing what once were the Ottomans (Pula, 2006, pp. 76-77)

In reality, while for Kadare, Albania's 'others' might have altered; it is hard to argue his contemplation of the 'AlbanianEuropean identity' has ever shifted. His late writing demonstrates that his interpretation is narrowed to the point that Albanians has no other choices but to join their motherland - Europe.

The Kadare-Qosja debate has divided most Albanian scholars who often side with one or the other. Professor Zekerija Ibrahimi from Skopje University supports Qosja for his realistic assessment of the Albanian composition, and also sides with him in criticising Kadare for idealism. Ibrahimi expressed his concern over the cultural and spiritual re-orientation of Albanians, who live in territories of ex-Yugoslavia for shifting their loyalties from Tirana towards Pristina (Ibrahimi, 20 April, 2006). Dukagjin Gorani argues that "Kosovo-Albanian society is focused on religious rights and [new] identities" (Gorani, December 2011, p. 289); an issue also discussed by Qosja. However, this matter requires more research, and it is not the focus of this paper. Others, like Xhavit Shala, defend Kadare and his emphasis on the west-European Christian origins of Albania (Shala, 9 May, 2006). In Qose-Kadare and the dynamic identity, Shala fails, however, in the same way that Kadare does, to recognise the dynamism of the Albanian identity and the fact that, historically, it has transformed to reflect elements of both East and West.

One of Kadare's historical rivals, the Albanian writer Dritëro Agolli, supports Qosja's arguments about Albanian identity. Agolli highlights the dynamism of the concept of identity, stressing that the Albanian identity, language, cultural and social habits have changed greatly and many more changes can be expected in the future (Agolli, 16 May, 2006). In his comments, however, Agolli neglects Albanian religious identity, focusing more on the dynamics of continuous social, cultural and political change.

Another Albanian writer and critic, Mustafa Nano, does not side with either Qosja or Kadare in his analyses. While for Nano, Kadare exaggerates in thinking that the Balkan nations added to the Ottoman culture "desire to become more European", Qosja perceives Albanian identity to be a mix of "oriental" and "occidental" components (M. Nano, 22 May, 2006). Furthermore, with 'anti-Kadare passion', Qosja equalises barbarian events of western-Europeans with those of easternOttomans. According to Nano, Albania's "eastern civilization" is not "autochthon and authentic" and, thus, Albania has no other choice but to follow its own culture, which, is similar to that of Europe since its birth (M. Nano, 22 May, 2006).

Aurel Plasari, another Albanian scholar, is instead criticising both Kadare and Qosja — Kadare for "nonsense" in claiming that the Albanian Christian church is older than the orthodox one, and Qose who is "mixing-up Istanbul with Jerusalem" (Plasari, 2012). Plasari is referring to Qosja's claim with regards to freedom of religion; that Christians can go for their religious rituals even to Turkey if they wish too (Plasari, 2012). Plasari thinks that the debate between Kadare and Qosja is beneficial for the Albanian nation, but also tells us there is much to be resolved concerning the question of Albanian national and religious identity. 
Visar Zhiti - an Albanian artist who was arrested during the Albanian Cultural Revolution in 1979 and released in 1987 highlights the importance of plurality as part of the national identity and states that both Kadare and Qose represent Albanian identity (Zhiti). Indeed, this is an important issue for Albania and must be further researched by scholars rather than conducting subjective analysis about Kadare and Qosja. Zhiti also points out that a big personality such as Mother Teresa should be left out of the debate, as she does not have the recognition she deserves in Albania. Unfortunately, Albanians are yet to understand the significance of Mother Teresa and what she represented for Albania and the entire world regardless of her religion. Nevertheless, the Albanian 'clash of civilisations' debate between Kadare and Qosja is a clear indication of how contested the Albanian national identity is.

As Zhiti mentioned, Kadare represents "Albanian aspirations and its national spirit" (Zhiti). The same thing can be said about Qosja's realistic picture to take into consideration the religion and other cultural elements that cannot be ignored. Nevertheless both Kadare and Qosja have been servants of the Albanian cause in the wider world.

\section{Concluding Remarks}

Ismail Kadare is one of the most prominent Albanian writers who contribute to defining the Albanian identity. He feels obliged to bridge the old Albanian millennia with the post-cold war period. Kadare is firm and not willing to compromise on his belief that Albania is part of Christian Europe; removed unjustly by Islamic Ottomans, temporary abandoned by the 'mother-Europe', who is now, one of those progressive forces that must help Albania rejoin its European family. Kadare offers fresh eyes to study the Albanian identity. Although his lens has its own strident focus, nevertheless, probing the Albanian identity from his perspective brings us closer to genuinely recognizing and acknowledging the complexity of defining it.

What Kadare underestimated in his thesis, is the fact that religion is not something than can be assumed and removed like an article of clothing and, once it has changed, it is difficult to shift again-especially after 500 years of the Ottoman domination in Albania and Kosovo. Nonetheless, only time will tell us whether the Albanian Muslim religion will again be 're-converted' to that of Christianity, remain to be a Muslim majority, or will never play an important role - as never did in the past.

The paper then analysed the ongoing Kadare-Qosja debate, which represents difficulties that the Albanian national identity is facing during its building stage. It was found that the theme of religion is always present on their analysis. However, despite making much of a religious dispute with Qosja, Kadare's theory is not religiously oriented. His main concern is to protect the Albanian people who suffered enough throughout history, from the repeated border incursions of the sixth century to the iron rule of the Communist Party in the last century.

\section{References}

[1] Agolli, D. (16 May, 2006). Intervistë për debatin e identitetit kombëtar Shqiptar [An interview over the debate of the Albanian identity], Shqip.

[2] Frashëri, K.). Identiteti i shqiptarëve dhe të metat e debatit Qose-Kadare [The Albanian identity and shortcomings of Qosja-Kadare debate]. Alba Soul. Retrieved 19 June, 2015, from

[3] http://www.albasoul.com/vjeter/modules.php?op=modload\&name=News\&file=article\&sid=1970

[4] Gawrych, G. W. (Novembre 1983). Tolerant Dimensions of Cultural Pluralism in the Ottoman Empire: The Albanian Community, 1800-1912. International Journal of Middle East Studies, 15(4), 519-536.

[5] Gorani, D. (December 2011). Orientalist Ethnonationalism: From Irredentism to Independentism Discourse analysis of the Albanian ethnonationalist narrative about the National Rebirth (1870-1930) and Kosovo Independence (1980-2000), unpublished thesis. School of Jurnalism, Cardiff University.

[6] Ibrahimi, Z. (20 April, 2006). Bregovici dhe Tatlisesi [The Bregovic and Tatlises]. Shekulli. 3 November, 2010, from

[7] http://www.shekulli.com.al/index.php?page=shownews\&newsID=94100

[8] Jing, K. (2013). The four others in I. Kadare's works : a study of the Albanian national identity. PhD Electronic Theses and Dissertations. University of Louisville. ThinkIR: The University of Louisville's Institutional Repository. Retrieved from 
[9] http://ir.library.louisville.edu/cgi/viewcontent.cgi?article=1729\&context=etd

[10] Kadare, I. (2006). Identiteti evropian i shqiptarëve [The European identity of the Albanians]. Tirana: Onufri.

[11] Kadare, I. (2011). Mosmarrëveshja: Mbi raportet e Shqipërisë me vetveten [Disagrement: On relations of Albania with itself]. Tirana: Onufri.

[12] Kadare, I. (2013a). Bisedë për brilantet në pasditen e dhjetorit [Conversation for brilliants on a December afternoon]. Tirana: Onufri.

[13] Kadare, I. (2013b). Secret relation Bisede per brilanted ne pasditen e dhjetorit [Conversation for brilliants on a December afternoon]. Tirana: Onufri

[14] Moisiu, A. (10 November, 2005). Toleranca ndërfetare në traditën e popullit shqiptar [The tolerance of Albanian Inter-religious tradition], lecture at Oxford Forum. Koha Jonë. 11 November 2011, from http://www.kohajone.com/lexo.php?id=42679

[15] Morgan, P. (2009). Ismail Kadare: The Writer and the Dictatorship, 1957-1990 London: Modern Humanities Research Association and Maney Publishing.

[16] Morgan, P. (2015). 'Strange commerce of memory and forgetting': Albania, Kosovo and Europe in Ismail Kadare's File on H.... (Manuscript, permission by the author).

[17] Nano, F. (12 September, 2002). Nuk u Globalizua Terrorizmi, por Lufta kunder tij [No globalisation of terrorism but the war against it instead]. 11 September 2011, from

[18] http://www.shekulli.com.al/shekulli/?s=Nano\%3A+Nuk+u+Globalizua+Terrorizmi\%2C+por+Lufta+kunder+tij

[19] Nano, M. (22 May, 2006). Kultura Perëndimore dhe Qytetërimi Lindor i Shqiptarëve [The Western Culture and the Oriental Civilization of the Albanians] 17 July, 2015, from http://albanur.eu/showthread.php?t=282

[20] Plasari, A. (2012). An interview with Aurel Plasari, "Debati për identitetin? Kadare ka nonsens, Qosja ngatërron Stambollin me Jeruzalemin" [Arguing about identity? Kadare has no-sense, Qose is mixing up Istanbul with Jerusalem] Shekulli. Retrieved 26 August, 2012, from http://shekulli.com.al/web/p.php?id=2847\&kat=104

[21] Pula, B. (2006). review of E. Sulstarova, Arratisje nga lindja: orientalizmi shqiptar nga Naimi te Kadare [Escaping from the East: The Albanian Orientalism from Naim to Kadare]. Albanian Journal of Politics, 2.

[22] Qosja, R. (3 May 2006). Idete raciste te Ismail Kadarese [The racist ideas of Ismail Kadare], Shqip.

[23] Qosja, R. (19 April, 2006). Premisa të gabuara [Wrong premises]. Takimi i Madh [The Great Meeting]. 5 May, 2015, from

[24] http://www.macedonianguide.com/rexhep_qosja/rexhep_qosja.html

[25] Qosja, R. (2006). Realiteti Shperfillur [Neglected Reality] Tirana: Toena.

[26] Shala, X. ( 9 May, 2006). Qose-Kadare and the dynamic identity, Shqip.

[27] Topalli mbështet Kadarenë: Kemi Identitet Evropian [Topalli support Kadare: We have European Identity]. (31 May, 2006). Shekulli Online. 11 January, 2011, from

[28] http://www.shekulli.com.al/shekulli/?s=\%E2\%80\%98Topalli+mbeshtet+Kadarene\%3A+Kemi+ldentitet+Evropia $\mathrm{n} \% \mathrm{E} 2 \% 80 \% 99$

[29] Topi, B. (7 February, 2008). Albania's Domestic and Foreign Policy 2008 Agenda. 23 February, 2011, from http://www.aiis-albania.org/

[30] Zhiti, V.). Kadare dhe Qose së bashku krijojnë identitetin tonë [Kadare and Qose together create our identity] Albanur. Retrieved 23 February, 2011, from http://albanur.eu/showthread.php?t=277 